\title{
AC 2004-297: LEADERSHIP THROUGH THE BACKDOOR: EXERCISES FOR INDIVIDUALS AND TEAMS
}

Doug Schmucker, Trine University 
Session 3615

\title{
Leadership through the Back Door: Exercises for Individuals and Teams
}

\author{
Douglas Schmucker \\ Western Kentucky University
}

Some say leaders are born. Others believe that they can be developed. In taking the latter perspective, this paper documents the creative integration of assignments that teach leadership skills without the students at first realizing this intent. Included are examples of assignments, how the assignments are integrated, rubrics used for assessing and evaluating student performance, and the courses in which the assignments are used.

\section{The Challenge \\ Leadership skills have traditionally fallen into the "soft skills" segment of engineering curricula if they exist in it at all. One prevalent perspective suggests that leaders are born. Leadership cannot be taught, only given the opportunity to flourish, says this perspective. Yet, both industry and academe call for professionals and graduates with greater team skills, communication skills, ethics training, life-long learning habits, and leadership skills. For example: \\ "Today, leaders must know much more than just technical proficiency - they must be able to communicate, build teams, motivate professionals, embrace diversity, and resolve conflicts."(ASME) ${ }^{1}$}

\section{The Approach}

A series of team-based and individual exercises were created to meet the "soft-skills" challenge. As the exercises and their evaluation and assessment tools were developed, it became apparent that leadership skills and effective team member skills share a great deal in common. It is through the back-door of completing these exercises and in reflecting upon that work that students simultaneously learn about and develop their leadership skills.

These exercises were inspired while implementing techniques from workshops such as USMA's Teaching Teachers to Teach Engineering ${ }^{2}$, ASCE's ExCEEd ${ }^{3}$, and ASEE's NETI ${ }^{4}$ and were primarily intended to meet challenges other than leadership training including:

- Improve team skills,

- Increase student understanding of the social context of civil engineering,

- Increase student participation in extra-curricular professional activities, and

- Develop life-long learning habits.

The exercises center around two course components: team-based assignments and (individual) professional development (PD) assignments. The team-based assignments include team training exercises as well as technical exercises. For the PD assignments, students select activities from a list; students may also prepare a proposal for an activity. The PD activities typically range from

\author{
Proceedings of the 2004 American Society for Engineering Education \\ Annual Conference \& Exposition \\ Copyright (c) 2004, American Society for Engineering Education
}


leading or participating in student professional societies to reading texts about historically significant civil engineering leaders. More details are provided later.

\section{The Through-the-Backdoor Leadership Model}

Models of leadership principles abound in publication. The characteristics of an effective leader that emerge in these exercises include:

- Spirit of helpfulness - goes above and beyond the basic responsibilities

- Good listener - will listen and attempt to understand other's perspectives

- Encourager - frequently encourages and praises others

- Questioner - asks questions when doesn't understand

- Explainer - willingly explains when others don't understand

- Accountable - holds others and self to appropriate level of accountability

- Productive and Efficient - efficiently uses resources (time, personnel, etc.)

- Idea Facilitator - positive contributor/facilitator towards team ideas

- Decision Maker - positive contributor/facilitator towards team decisions

- Character - displays high level of integrity and ethical behavior

These characteristics arise both from the PD assignments and from team assessment tools, principally those from Brown ${ }^{5}$ and Rogers and Sando ${ }^{6}$. The Autorating form of Brown prompts the student to evaluate each team member on a nine-level qualitative scale. The scale ranges from "No Show" to "Excellent" as shown in Table 1. Note the emphasis here on helping other team members and being dedicated to their responsibilities as opposed to academic ability. The qualitative rankings are assigned integer values from 0 to 8 from which factors to adjust individual scores may be determined.

\section{Table 1 Autorating Team Citizenship Rating Rubric}

\begin{tabular}{ll}
\hline Rating & Description \\
\hline Excellent & Consistently went above and beyond, e.g., tutored teammates. \\
Very Good & Consistently did what he/she was supposed to do, very well prepared and cooperative. \\
Satisfactory & Usually did what he/she was supposed to do, acceptably prepared and cooperative. \\
Ordinary & Usually did what he/she was supposed to do, minimally prepared and cooperative. \\
Marginal & Sometimes failed to show up or complete assignments, rarely prepared. \\
Deficient & Often failed to show up or complete assignments, rarely prepared. \\
Unsatisfactory & Consistently failed to show up or complete assignments, unprepared. \\
Superficial & Practically no participation. \\
No Show & No participation at all \\
\hline
\end{tabular}

The Rogers and Sando forms prompt the student to reflect in directed ways about their own contribution to the team as well as team functioning. Leadership associated items are shown in Table 2. For instance, in the personal evaluation sheet, a student responds to how often they were "an active participant, listened to everyone on my team, encouraged and praised others on my team, helped someone who didn't understand, and asked for clarification." Note how this compares favorably to the $\mathrm{ASME}^{1}$ description of what leader must be able to do. The team evaluation sheet provides categories for team effectiveness in areas of "use of time, development of ideas, decision making, and productivity." 
Table 2 Leadership Associated Items from Personal Evaluation Sheet, Rogers and Sando

\begin{tabular}{lccccc}
\hline Response Item & A lot & & & Not at all \\
\hline 1. I was an active participant in my team. & 4 & 3 & 2 & 1 & 0 \\
2. I listened to everyone on my team. & 4 & 3 & 2 & 1 & 0 \\
3. I encouraged and praised others on my team. & 4 & 3 & 2 & 1 & 0 \\
4. I explained/helped someone who didn't & 4 & 3 & 2 & 1 & 0 \\
$\quad \begin{array}{l}\text { understand. } \\
\text { 5. }\end{array}$ & & & & \\
$\quad$ understand. & 4 & 3 & 2 & 1 & 0 \\
\hline
\end{tabular}

\section{The Plan}

All results discussed here were gathered while the author taught at Valparaiso University and included a variety of class-levels and types. Classes ranged from a third semester statistics course to an upper-level design course (Table 3). When formal teamwork was used in a course, it was accompanied with at least one lesson in team training. Formal teamwork here is defined as instructor-selected teams, charters created by each team, and a formal feedback process. Although potentially valuable, simply telling students that they can submit homework in selfselected teams with no formal process to analyze team functioning does not constitute formal teamwork. Students worked in groups for all coursework except the self-selected PD activities.

Table 3 Courses and Associated Exercises

\begin{tabular}{lll}
\hline Semester & Course & Type of Exercise \\
\hline $3^{\text {rd }}$ & $\begin{array}{l}\text { Applied Probability and } \\
\text { Statistics in Civil Engineering }\end{array}$ & $\begin{array}{l}\text { Team Training } \\
\text { Team Assessment } \\
\text { Professional Development }\end{array}$ \\
$5^{\text {th }}$ & Structural Analysis & Professional Development \\
$6^{\text {th }}$ or $8^{\text {th }}$ & Structural Steel Design & $\begin{array}{l}\text { Team Training } \\
\text { Team Assessment } \\
\end{array}$ \\
& & Professional Development \\
& \\
\hline
\end{tabular}

Team Training Exercise

The team training exercise was originally developed at the Schreyer Institute at Penn State. It revolves around a fictional case study where an important on-campus structure has collapsed. Via discussion with the original design team and a forensic investigation of the collapsed facility, the "dean" of engineering has identified two sources of problems associated with the collapse: 
technical problems and team dysfunction. An alumna of the university summarized the team problems with:

I thought that by doing well in my coursework at Vale, I was preparing myself for my career. However, it obviously wasn't enough. The whole project was a disaster; we were perpetually behind, constantly duplicating or overlooking important tasks, and even when we finished, none of us were satisfied with the design. A few of us slaved over this project, but it is obvious that the amount of "effort" did not ensure success. It also appeared that some of the critical team members were far more interested in scheduling golf games with the C.E.O. than checking their work. After this catastrophe, I wonder if I will ever work as an engineer again. The guilt over "Bully" has sent me to a grief therapist. (Bully the bulldog was the college's mascot; he died during the collapse.)

Each student team is prompted to answer questions such as:

1. Group structure: How should the dean select team members? What factors should be considered?

2. Preparation: Should the dean take time to prepare the team members with guidelines, training, and background information on effective teams to ensure a success? If so, what should be included and how should the material be presented to the group?

3. Assessment: How should the dean evaluate the team's work? By individuals or as a group? In what ways can the dean discourage or eliminate slackers?

4. Trouble-shooting: How could the dean deal with a dysfunctional team? How could the dean help team members deal with dysfunction?

In the six years that this author has used this scenario, students never failed to provide responses that were similar to what experts suggest are characteristics of high-performing teams. For example, students recommend to the dean that:

- Teams should be comprised of members with complementary skills pertinent to the job including "people" skills;

- Training should be provided in organizing the team, defining roles of responsibilities, rewards and punishments;

- Both individual contributions and overall team effectiveness should be reviewed and rewarded;

- There should be specific guidelines for what constitutes good and poor performance;

- There should be a specific mechanism in place for conflict resolution; and,

- The dean should define the broad goals of the project but allow the team to decide how to get there, i.e., team autonomy, etc.

Note:

- The students inherently defined not only the characteristics of a successful team environment but the characteristics of a highly effective leader!

- The exercise is itself a role model for what the students think is effective leadership! (This is something that even a few students figure out for themselves and comment upon.)

After this exercise, the students are provided recommendations for forming their teams. The template for the charter is fixed, but teams could chose their own organizational structure, roles of responsibility, role rotation schedule, etc.

Proceedings of the 2004 American Society for Engineering Education

Annual Conference \& Exposition

Copyright (c) 2004, American Society for Engineering Education 
Team Assessment Training Exercise

After several years of using team-based course work, it became apparent that not all students used the same standard of care in completing the forms. With assistance from Rich Layton of Rose-Hulman Institute of Technology, a training exercise was created to "train" the students how to complete the Autorating form. This exercise is another case-study where descriptions are provided of the behavior of each member of a fictional team. Students then evaluate each fictional team member first by themselves and then with their team. This exercise occurs at the mid-semester mark just prior to the students doing their own mid-semester individual and team assessments. In addition to providing an organized approach to completing the form, students also see a diversity of opinion about the contributions of team members. After the exercise, students typically arrive at a fairly reasonable consensus about expectations of performance.

\section{Team Evaluation}

At the end of the semester, each student completes a final team evaluation. The students also allocate a fictional bonus of 100 points amongst their team members. These allocations can be used to develop individual adjustment factors similar to the manner of the Autorating form. This factor is formed by dividing the average allocation given a student by the average allocation of the entire team (100 divided by the number of team members). Interestingly, the statistical correlation between this numeric-based perspective of individual contribution to team success is above $80 \%$ with that from the qualitative-based Autorating instrument. That is, there exists a strong positive linear correlation between the numeric and qualitative based adjustment factor.

\section{Professional Development Activities}

The primary objective of introducing PD exercises was to increase the level of student participation in out-of-class activities such as ASCE. It also serves as a "home" for the Rising Tide assignment discussed later. Approximately 10\% of the course grade is associated with students completing PD assignments. Students typically earn points by participating in activities such as student society meetings, guest speakers, town hall meetings, etc. In order to receive credit, students prepare a memo summarizing the importance and relevance of the event to their careers.

Relative values for the activities during AY2001-02 are shown in Table 4. Note that "leadership" positions were rewarded more highly than "participation" activities. Students choose their own series of activities with the goal of earning 100 points for the semester. Some of the more highly attended PD activities were joint student-chapter and professional sectional ASCE meetings. 
Table 4 Professional Development Actitivies - AY 2001-02

\begin{tabular}{|c|c|c|c|}
\hline & Activity & Participation Level & Points \\
\hline \multirow{5}{*}{ ASCE } & Student Chapter Meetings & Attendance & 5 \\
\hline & NWI Branch Meetings & Attendance & 20 \\
\hline & Indiana Section Meeting (Spring) & Attendance & 20 \\
\hline & Pro. Dev. Seminar at Purdue (Nov.) & Attendance & 20 \\
\hline & $\begin{array}{l}\text { Holding a student office or organizing an event. } \\
\text { Submit proposal to instructor. }\end{array}$ & Participation & TBD \\
\hline \multirow{6}{*}{$\begin{array}{l}\text { College of } \\
\text { Engineering }\end{array}$} & ASME, IEEE, SWE, SAE, TBP Meetings & Attendance & 5 \\
\hline & TED Banquet (Spring) & $\begin{array}{l}\text { Attendance } \\
\text { Participation }\end{array}$ & $\begin{array}{l}5 \\
5\end{array}$ \\
\hline & Outside Speaker Presentations & Attendance & TBA \\
\hline & $\begin{array}{l}\text { CE Senior Project Presentations } \\
\text { See instructor for other ME/ECE pres. }\end{array}$ & Attendance & $\begin{array}{l}5 \text { per day for mid-term } \\
\text { and } 5 \text { for final }\end{array}$ \\
\hline & Design Expo (Spring) & Participation & 10 \\
\hline & Tau Beta Pi People Skills Module (Spring) & $\begin{array}{l}\text { Attendance and } \\
\text { Participation }\end{array}$ & 10 \\
\hline \multirow{4}{*}{ Career Center } & Mock Interview (One time only) & Participation & 5 \\
\hline & Career Fair & Attendance & 5 \\
\hline & Consultation (One time only) & Attendance & 5 \\
\hline & Etiquette Dinner (Oct. 30) & Attendance & 20 \\
\hline \multirow{2}{*}{ Misc. } & FE Exam & Sitting for Exam & 25 \\
\hline & Class Field Trips (if applicable) & Attendance & 20 \\
\hline
\end{tabular}

\section{Rising Tide Exercise}

A significant component of the PD-affiliated courses not shown in Table 4 is an old-fashioned reading and writing assignment. The assignment in various classes was selected so that prior to graduation each civil engineering student would have read Rising Tide: The Great Mississippi Flood of 1927 and How it Changed America ${ }^{7}$. This historical narrative traces ...

“... the history of the nation's most destructive natural disaster ... explains how ineptitude and greed helped cause the flood, and how the policies created to deal with the disaster changed the culture of the Mississippi Delta. Existing racial rifts expanded, helping to launch Herbert Hoover into the White House and shifting the political alliances of many blacks in the process. An absorbing account of a little-known, yet monumental event in American history, Rising Tide reveals how human behavior proved more destructive than the swollen river itself."

Part One of this narrative focuses on the pertinent engineering related history beginning in the mid- $19^{\text {th }}$ century that contributed to and even magnified the flood's effects. Within this part, the reader discovers some of the most influential civil engineers in this country's history including 
James Buchanan Eads, Andrew Atkinson Humphreys, chief of the U.S. Army Corps of Engineers, as well as President Hoover.

This narrative provides a clear picture of the qualities that made these men such important leaders of their time, both in positive and negative ways. In so doing, the Rising Tide assignment forces the students to come face-to-face with:

- Snap-shots of (in)effective leaders and leadership skills,

- Examples of (un)ethical professional conduct,

- Implications of civil engineering facilities on the public's safety, health, and welfare,

- Global context of engineering,

- Role of engineers in formulating public policy,

- Moxie, i.e., ability to face trials and travails.

The writing portion of the assignment requires that students comment upon their interaction with the text, particularly in how it contributes to their new understanding of the engineering profession. The evaluation rubric provides a direction to several of the bulleted ideas above.

Grading Criteria for the Rising Tide writing assignment. An "A" paper will:

- Discuss how the professional and social climates interacted in ways that helped or hindered the engineering process.

- Discuss the importance of political, social, and business skills to civil engineer's success.

- Discuss the ethical behavior of the principal engineers.

- Discuss how each of these contributes to your understanding of the practice of civil engineering.

- Will weave each of the points above (and others as you see fit) into a cohesive essay.

- Show a commitment to excellence in preparation, including professional appearance and an understanding of standard English.

DO NOT:

- Answer each bullet above in the manner of an organizational checklist.

- Write a summary of the text.

- Write your opinion about whether you liked the text or not.

ADDITIONAL PD WRITING ASSIGNMENTS

Other texts used for the PD writing assignments included:

- Sons of Martha ${ }^{9}$

- To Engineer is Human ${ }^{10}$

- The Johnstown Flood ${ }^{11}$

- Engineers of Dreams ${ }^{12}$

- Getting Sued and Other Tales of the Engineering Life ${ }^{13}$

Although each of these texts have different levels of focus on topics such as leadership, ethics, et.al., the overall effects are similar to Rising Tide. Hence, the evaluation rubrics were similar. 


\section{EVALUATION OF RESULTS}

Recall that the majority of these exercises were directly intended for topics other than leadership skills. Fortunately, the close association and/or overlap with the direct topics and leadership skills provide a means of inference of student performance. The outcomes shown in Table 5 were measured by performance on the assignments or by instructor observation, where appropriate.

\section{Table 5 Summary of Student Performance}

\begin{tabular}{|c|c|}
\hline Exercise & Student Performance \\
\hline \multicolumn{2}{|l|}{ Team-Based } \\
\hline Team Training & $\begin{array}{l}\text { - Team charters explicitly include leadership roles and definitions } \\
\text { of those roles. } \\
\text { Less than } 10 \% \text { of the students observe without prompting that } \\
\text { this exercise is in itself an example of leadership by the } \\
\text { instructor. }\end{array}$ \\
\hline Team Assessment Training & $\begin{array}{l}\text { - Students observe diversity of opinion about contributions of } \\
\text { "fictional" students; } \\
\text { - Data shows increased student satisfaction with the team forms } \\
\text { used to make individual grade adjustments, particularly for } \\
\text { "slackers." }\end{array}$ \\
\hline Team Evaluation & $\begin{array}{l}\text { - Approximately } 70 \% \text { of teams functioned according to their } \\
\text { charters including following roles of responsibility; } \\
\text { - Only } 50 \% \text { of teams followed their rules about rotating roles. } \\
\text { - Strong and positive correlation between qualitative-based and } \\
\text { numeric-based individual adjustment factors. } \\
\text { - Approximately } 15 \% \text { of teams clearly demonstrated dysfunctional } \\
\text { behavior. }\end{array}$ \\
\hline \multicolumn{2}{|l|}{ Professional Development } \\
\hline $\begin{array}{l}\text { Participation and Attendance } \\
\text { Activities }\end{array}$ & $\begin{array}{l}\text { - Approximately } 90 \% \text { of students participate sufficiently to earn } \\
\text { full points in course grade component. } \\
\text { - Approximately three-fold increase in participation in ASCE } \\
\text { student chapter activities. } \\
\text { - Only moderate success at improving student attitudes with } \\
\text { regard to ASCE activities. } \\
\text { - When not a part of PD points, attendance at ASCE activities } \\
\text { returned to low-level. }\end{array}$ \\
\hline Rising Tide & $\begin{array}{l}\text { - Approximately } 30 \% \text { of students performed " } \mathrm{A} \text { " level work as } \\
\text { defined by the grading rubric. } \\
\text { - Approximately } 80 \% \text { of students performed "C" level work or } \\
\text { higher. } \\
\text { - Approximately } 25 \% \text { of students drew clear connection between } \\
\text { the assignment and leadership skills. } \\
\text { - Approximately } 50 \% \text { of students drew at least a partial connection } \\
\text { between the assignment and leadership skills. }\end{array}$ \\
\hline Additional Texts & $\begin{array}{l}\text { Smaller percentages than Rising Tide partially due to the different } \\
\text { emphases of texts. }\end{array}$ \\
\hline
\end{tabular}


Amongst the multi-fold learning outcomes, one general conclusion is that at least $50 \%$ of the students are drawing an association between these exercises and leadership skills. This is based upon student work that explicitly associates behavior with success or lack thereof. In the case of the team-based experiences, the students have an opportunity to practice these skills directly. The writing assignments permit them to learn by "observing" others in the form of reading and then reflecting upon historical figures.

Of some concern was the attitude of the students to ASCE leadership opportunities. With the significant increase in attendance at ASCE student-chapter events, one might have hoped for a corresponding increase in numbers on the ballot for officer positions. This did not occur. Unfortunately, the student chapter president resisted applying the very principles espoused in the team training exercises. In short, despite many other positive attributes, the student-chapter president micro-managed the chapter and did not attempt to involve other students in leadership activities, preferring to run most activities by himself. The level of dialogue amongst student members and faculty co-advisor made the diagnosis of this unfortunate situation clear.

At the time of implementation of the PD activities, only about $30 \%$ of the civil engineering students could have been reasonably described as "active" participants in ASCE. The term "active" here is defined as attending at least three student chapter activities during a semester. After implementation, the level of "active" participation rose above $80 \%$ with "partial" participation near $90 \%$. This data is only approximate; complete attendance records are not available.

Attendance figures at student-chapter events dropped sharply after the "PD points" incentive was dropped for ASCE student chapter events. This was probably primarily associated with the grade-orientation of the students rather than rapport problems with chapter officers. The reason for dropping these events from the approved events list was that attendance roles were not reliable; this despite the existence of an otherwise well functioning honor system at the university.

Of some interest are the results from the Rogers and Sando forms. The personal evaluation sheet uses a Lichert style scale with five possible responses. Most students appeared to offer relatively frank self-appraisals as evidenced by numerous responses through-out the scale including their own performance. For example, when asked to respond how often they "encouraged and praised others on my team," responses range from "Yes, a lot" to "No, not at all." The average on this "4" to "0" scale, respectively, was approximately 2.5. Similar but slightly higher results apply for the "listening" response. Based upon personal observations of student behavior both in and out-of the team environment, this suggests a somewhat balanced, although most likely "rosy" student perspective. Responses from the team evaluation sheet indicate more variable responses and slightly lower average responses. As might be expected, students appeared to be more rosy about their own behavior than the overall team behavior.

What did come out clearly was the association between high-performing teams in terms of grades on projects, individual grades on exams, and strongly positive scores on the team forms. These observations are only moderately correlated with GPA. In other words, having an "A"

Proceedings of the 2004 American Society for Engineering Education

Annual Conference \& Exposition

Copyright (c) 2004, American Society for Engineering Education 
student on the team clearly did not necessarily mean a high performing team nor a high team project grade.

\section{PRIMARY BENEFITS OF THE EXERCISES}

For curricula that are already jammed with technical content, these exercises provide a significant variety of learning opportunities for each student including:

- Leadership skills

- Team skills

- Ethics training

- Global context of engineering

- Life-long learning habits

The exercises come at a relatively low cost in terms of student time particularly since some of the reading assignments can be assigned even before a class begins. For example, providing registered students before Christmas Break their PD writing assignment for the spring semester. The low cost is also in terms of being able to use the same assignments for many different types of learning outcomes. The cost becomes incrementally less when one applies these techniques in a gradual manner over several semesters. The longer "gestation" period permits the student to mature as they come in closer contact with the practicing world via co-operative or summer work experiences. There was a distinct and obvious "spike" of positive student response to all of these activities after an ASCE professional chapter panel discussion. In this discussion, three practicing engineers each commented that one of the keys to their long-term professional success included the ability to communicate --- written, reading, verbal, and listening skills.

\section{PRIMARY IMPROVEMENTS TO THE EXERCISES}

Although the cost of these exercises is relatively low and the student benefits large, the implementation and evaluation schemes need improvement. In particular, keeping track of all the PD events, student attendance, and points begins to be a bit cumbersome. There is also perhaps great benefit in having all students in a class read the same text rather than providing student choice. The primary reason for this is that the exercise can be leveraged into a far greater impact via the common reading. For instance, one could set aside a lesson for an in-class debate or discussion. It is just this sort of activity that will ensure that there is a higher level of reflection across the entire set of students.

The most significant area of improvement remains the evaluation of student work. It is perhaps even more important with essay style assignments to review and provide feedback in a timely fashion. The students feel that these assignments are a bit odd to begin with; hence, the instructor must be just a bit more on top of the game. On the other hand, if one is content to simply "expose" students to concepts, then these exercises are extremely low cost, especially if one can find someone else to perform the writing analysis and evaluation such as an English graduate student. However, this author would submit that is the instructor's ethical obligation to review these works his or herself. The students do tend to invest themselves in this work and expect a corresponding effort from their professor. 
Of greatest need of improvement are the rubrics and data processing. The rubrics need to be modified to more explicitly include leadership skills. The author is also exploring the application of Lowman's Two-Dimensional Model for Effective College Teaching. ${ }^{14}$ The descriptors of exemplary teachers in Lowman's model compare well with descriptors of exemplary leaders. For example, "enthusiastic," "inspiring," "organized," "prepared," "stimulating," "communicative," "caring," "available," "accessible," "approachable," "respectful," "fair," "patient," "dedicated," "committed."

\section{Bibliography}

1. ASME International, Leadership Principles, Professional Practice Curriculum Online, http://www.professionalpractice.asme.org/leadership/principles/, accessed 13 January 2004.

2. Conley, C.H., Ressler, S.J., Lenox, T.A., Samples, J.W., "Teaching Teachers to Teach Engineering - T⿱4$E$," Journal of Engineering Education, January 2000, pp. 31-38.

3. ASCE Program Design Workshop, "A Model for Faculty Development in Civil Engineering: The ExCEEd Teaching Workshop,” ASCE, July 1999.

4. National Effective Teaching Institute (NETI), Seattle, WA, ASEE, June 25-27, 1998.

5. Brown, R.W., "Autorating: Getting individual marks from team marks and enhancing teamwork," Proc. Frontiers in Education Conference. IEEE/ASEE, Pittsburgh, November (1995).

6. Rogers, G.M., and Sando, J.K., "Stepping Ahead: An Assessment Plan Development Guide," Rose-Hulman Institute of Technology, Office of Publications, 1996.

7. Barry, J., Rising Tide: The Great Mississippi Flood of 1927 and How it Changed America, Simon \& Schuster Trade, 1998.

8. Amazon.com, Editorial Reviews of Rising Tide, accessed 13 January 2004.

9. Fredrich, A, (ed) Sons of Martha: Civil Engineering Readings in Modern Literature, ASCE Press.

10. Petroski, H., To Engineer is Human: The Role of Failure in Successful Design, St. Martin's Press, 1985.

11. McCullough, D., The Johnstown Flood, Simon \& Schuster, 1968.

12. Petroski, H., Engineers of Dreams: Great Bridge Builders and the Spanning of America, Vintage Books, Random House, 1996.

13. Meehan, R., Getting Sued and Other Tales of the Engineering Life, Cambridge, Mass., MIT Press, c1981.

14. Lowman, J., Mastering The Techniques Of Teaching, 2nd Ed., Jossey Bass, 1995.

\section{Biographical Information}

Dr. Schmucker teaches in the Dep't. of Engineering at Western Kentucky University. He graduated from Valparaiso University with a B.S.C.E. in 1990 and earned M.S. and Ph.D. degrees from Stanford University in 1991 and 1996, respectively. He has taught courses in mechanics, structural analysis and design, soil mechanics, probability and statistics, and civil engineering materials at Penn State, Valparaiso, and Western Kentucky Universities. 